\title{
Semiotika Rupa Topeng Malangan \\ (Studi Kasus: Dusun Kedungmonggo, Kec. Pakisaji, Kabupaten Malang)
}

\author{
Wulan Astrini, Chairil Budiarto Amiuza, dan Rinawati P. Handajani \\ Jurusan Arsitektur, Fakultas Teknik, Universitas Brawijaya \\ Alamate-mail penulis : wulanastrini@yahoo.com
}

\begin{abstract}
ABSTRAK
Studi ini dimaksudkan untuk menelusuri konfigurasi visual rupa yang membentuk tatasusunan, kegunaan dan makna dalam hubungannya dengan rona, serta gerak dan sifat konfigurasi visual rupa pada karya seni topeng Malangan tersebut. Hasil penelitian ini secara teoritik dapat menjelaskan hubungan antara dimensi visual dan fungsi karya rupa dalam membentuk bahasa tanda dan makna, yang diharapkan dapat digeneralisir untuk karya seni rupa sejenis dan dijadikan dasar metode transformasi desain yang berkarakter lokal. Penelitian ini memadukan pendekatan kualitatif dengan metoda survei. Instrumen utama berupa rekaman foto dan gambar fisik konfigurasi visual rupa topeng. Instrumen pendukung berupa wawancara dengan pelaku, pengrajin, dan seniman topeng Malangan di Dusun Kedungmonggo, Kecamatan Pakisaji, Kabupaten Malang. Penelitian ini menggunakan responden yang dipilih secara porposive sampling. Data yang diperoleh dari responden dikompilasi untuk memperoleh gambaran obyekobyek visual rupa yang mewakili dalam lingkup kesenian topeng Malangan. Hasil konfigurasi visual, gerak, ruang, dan musik yang diperoleh dari analisis hubungan diantaranya, selanjutnya diinterpertasi melalui wawancara, dianalisis untuk memperoleh gambaran menyeluruh konfigurasi seni rupa, seni gerak, seni pentas (ruang), seni musik (audio) topeng Malangan sebagai karya budaya lokal.
\end{abstract}

Kata kunci: semiotika, visual rupa, topeng Malangan

\begin{abstract}
This study is intended to explore the visual configuration in such a form governance structure, the usefulness and meaning in conjunction with hue, and motion and visual properties of such a configuration on the Malangan mask. Theoretical results of this study may explain the relationship between visual dimensions and functions of visual arts in shaping the language of signs and meanings, which are expected to be generalized to a kind works of art and design transformation methods form the basis of a local character. This research combines qualitative approaches with a survey method. The main instrument in the form of pictures and recordings of physical configurations such visual mask. Supporting instrument in the form of interviews with actors, craftmen, and artists in Malangan mask at Kedungmonggo, Pakisaji District, Malang Regency. This study uses selected respondents porposive sampling. Data obtained from respondents compiled to obtain an overview of visual objects that represent the scope of the visual arts Malangan mask. Results of visual configuration, motion, space, and music derived from the analysis of the relationship between them, then interpreted through interviews, analyzed to obtain an overall picture configurations art, art movement, art performances (space), music (audio) of Malangan mask as cultural work local.
\end{abstract}

Keywords: Semiotics, visual appearance, Malangan mask 


\section{Pendahuluan}

Kesenian wayang topeng mengalami perkembangan seirama dengan perkembangan alam pikiran manusia pendukungnya. Perkembangan ini tampak dalam wujud bentuk, teknik pakeliran, dan peranannya dalam kehidupan manusia. Sementara manusia hidup dalam alam pikiran animis, kesenian wayang topeng umumnya selalu dikaitkan dengan ritus yakni dimanfaatkan sebagai media pemujaan terhadap roh leluhur. Oleh sebab itu ia mempunyai sifat yang sakral. Dalam perkembangan fungsinya, kini wayang topeng yang ada di Dusun Kedungmonggo dikenal sebagai seni rupa, tari dan pertunjukan. Wayang topeng Malangan dengan fungsi yang dimiliki oleh wayang topeng sebagai kesenian tradisional sebenarnya juga sebagai penggerak dalam kesenian tradisional lainnya. Sebagai penggerak terhadap kesenian tradisional seperti ludruk Malangan, wayang kulit Malangan maupun tayub Malangan. Mengingat dalam wayang topeng terdiri dari perpaduan macam-macam unsur seni (seni tari, suara, musik, lukis, pahat, dan pentas) maka dimungkinkan kiranya untuk bisa dapat dipergunakan sebagai salah satu bagian dari objek pariwisata di daerah Kabupaten Malang.

Di Kabupaten Malang, kesenian tradisional wayang topeng tidak hanya pada satu tempat melainkan tersebar di beberapa daerah yaitu di Tamiajeng, Nduwet, Precet, Pucangsongo, Wangkal, Gubuklakah, Jambesari, Jedungmonggo, Jabung, dan Glagahdowo. Namun dewasa ini hanya tinggal beberapa kelompok wayang topeng yang masih bertahan dan banyak diantaranya didesak mundur oleh tontonan-tontonan baru yang lebih digemari oleh masyarakat setempat. Beberapa pecinta budaya muncul kekawatiran akan kepunahan wayang topeng ini. Oleh karena itu, peneliti juga berusaha ikut mengambil peran dalam pelestarian kesenian wayang topeng Malangan dengan mengambil salah satu gaya wayang topeng Malangan yang masih dipertahankan secara turun temurun yakni wayang topeng Kedungmonggo untuk dijadikan obyek penelitian.

Untuk itu segala upaya dalam rangka ikut menjaga keberadaan wayang topeng Malangan khususnya perlu dilakukan. Perlu diingat bahwa daerah kabupaten Malang juga merupakan salah satu jalan alternatif koridor wisata panorama, seni dan kuliner. Salah satu upaya pelestarian menjaga kesetimbangan dan keselarasan budaya kearifan lokal yang dapat dilakukan oleh akademisi melalui kajian semiotika rupa karya seniman rakyat tersebut, dimulai dari penelusuran kondisi dan potensi unsur-unsur rupa dan prinsipprinsip rupa tradisi topeng, mencari-temukan manfaat-guna dan arti-makna unsur-unsur rupa dan prinsip-prinsip rupa tradisi topeng dalam proses dan konsep desain masyarakat setempat dan seniman, artis dan arsitek.

\section{Bahan dan Metode}

\subsection{Semiotika dalam Desain}

Dalam lingkup budaya Umberto Eco, semiotik dapat dipakai untuk mengamati berbagai tanda yang bersifat empiris dan indrawi (Eco, 1984). Tanda tanda yang bersifat empiris anatu indrawi dapat mencakup tanda tanda lingkungan alam seperti lanskap, cuaca, peristiwa alam, lingkungan artifisial seperti arsitektur permukiman, rumah tinggal, ekterior, interior dan ragam hias dan sebagainya. Dalam uraian selanjutnya, kajian semiotika meliputi seluruh wahana intelektual manusia, tanda alamiah dan peradaban yang dikenal sebagai ranah budaya, antara lain: 
a. Komunikasi visual (Visual Communication), kajian yang meliputi sistem grafis, warna, tanda tanda ikon, simbol dan sebagainya.

b. Sistem obyek (Systems of Objects), meliputi arsitektur, kota, lansekap dan sebagainya.

Bagi Pierce, semiotika adalah sinonim logika. Artinya bahwa manusia hanya berfikir dengan tanda (Roland, 1985). Demikian ilmu tanda atau semiotika dapat dijadikan alat untuk menelusuri sesuatu dan menghasilkan sesuatu berupa tanda-tanda atau simbolsimbol. Dalam uraian selanjutnya, bahwa tanda-tanda tersebut berdasarkan relasinya terdiri dari:

a. Semiotik Sintaksis, aktifitas yang mempelajari tanda dalam sistim tanda yang lain yang menunjukkan kesamaam atau kerjasama.

b. Semiotik Semantik, mempelajari hubungan antara tanda dan maknanya atau denotasi dan konotasi dari tanda tanda tersebut.

c. Semiotik Pragmatik, mempelajari hubungan tanda dengan pemakainya.

\subsection{Model Kajian Semiotika Bahasa Rupa}

Tinjauan Semiotika bahasa rupa merupakan hal yang tidak mudah dilakukan, hal itu dikarenakan karakter kebahasaannya yang bersifat Organik dan kerap tidak memiliki gramatika yang diterima dalam kesepakatan yang terukur dan Rasional. Dalam kajian semiotika, bahasa rups juga dapat diamati sebagai suatu sistim tanda, baik tanda tunggal maupun sekumpulan tanda (Sachari,2004).

Dalam pengamatan tinjauan desain, tautan pengamatan bahasa rupa dapat berupa narasi sejarah, gaya desain, karya rupa, artifak, mashab estetika, proses mendesain,maupun figur desainer. Dalam tinjauan bahasa rupa terdapat dua aspek penting semiotika, yaitu indek dan tanda (ikon, simbol). Indek adalah tanda yang memiliki hubungan ketergantungan eksistensial antara tanda dan yang ditandai, atau mempunyai ikatan kausal dengan apa yang diwakilinya. Sedangkan Tanda adalah unsur dasar dalam semiotika dan komunikasi, yaitu segala sesuatu yang mengandung arti, yang memiliki dua kategori yaitu sebagai penanda dan petanda (Sachari,2004).

\subsection{Model Kajian Bahasa Rupa Tradisional Jawa}

Kajian Bahasa Rupa Tradisional Jawa dapat ditelusuri dari sisi historis, falsafah, dan karakteristik semiotikanya. Sisi historis sebagai indek kezamanan yang setiap kezamanan memiliki tanda, ikon, dan simbol tertentu. Sisi falsafah, falsafah hidup kesenian upacara sebagai indek yang masing-masing memiliki tanda, ikon, dan simbol tertentu. Sisi karakteristik, karya rupa sebagai indek yang unsu-unsur karya tersebut memiliki tanda, ikon, dan simbol tertentu pula.

\subsection{Pendekatan Semiotik dalam desain Rupa}

Penjelasan semiotika, rupa, dan hubungannya dapat ditarik kesimpulan bahwa desain rupa apapun sebagai bahasa visual dapat ditelusuri atau dikaji lewat media bahasa tanda atau simbol yang terkadung didalamnya. Sintaksis menegaskan pengetahuan tentang gabungan elemen-elemen atau unsure-unsur desain. Unsur desain yang mana yang dapat dikombinasakan?, bagaimana caranya?, untuk apa? (Zahnd, 2009). Pembentukan elemen rupa berkaitan dengan penataan yang juga mengikuti aturan pola yang ada dalam sintaksis rupa. Sintaksis rupa melibatkan mofologi dari empat aspek secara langsung sebagai berikut: 
a. Sintaksis bentuk, memperhatikan kombinasi semua elemen rupa yang berkaitan dengan bentuk.

b. Sintaksis material, memperhatikan kombinasi semua elemen rupa yang bersifat material atau berkaitan dengan bahan.

c. Sintaksis fungsi, memperhatikan kombinasi semua elemen arsitektur ysng bersifat atau berkaitan dengan fungsi.

d. Sintaksis struktur, memperhatikan kombinasi semua elemen rupa yang bersifat atau berkaitan dengan struktur.

Zahnd (2009) juga menjelaskan adanya empat aspek semantik dalam satu obyek, yaitu:

a. Referensi : sebuah obyek rupa memiliki ciri ciri yang dapat dihubungkan dengan kode tertentu yang dikenal umum.

b. Relevansi : sebuah obyek rupa memiliki ciri ciri yang dapat dihubungkan dengan fungsi tertentu yang dikenal umum.

c. Maksud : sebuah obyek rupa memiliki ciri ciri yang dapat dihubungkan dengan maksud tertentu yang dikenal umum.

d. Ekspresi : sebuah obyek rupa memiliki ciri ciri yang dapat dihubungkan dengan nilai tertentu yang dikenal umum.

Adapun semantik arsitektur memiliki empat variabel sebagai berikut:
a. Bentuk/Wujud
b. Ukuran/Skala
c. Bahan/Konstruksi
d. Letak/Posisi

Aspek prakmatik sering menjadi kriteria utama dalam realitas desain rupa. Kenyataan tersebut menentukan karya rupa bermanfaat atau tidak. (Zahnd, 2009). Aspek pragmatik arsitektur mencakup variabel sebagai berikut:

a. Yang membuat

b. Pemakai

c. Fungsi/guna

d. Waktu/lama dibuat

e. Lokasi

f. Teknik membuat

g. Teknik pembuatan

h. Pihak yang terlibat

i. Sarana dan prasarana

\subsection{Metode Penelitian}

Pengumpulan data dalam penelitian ini terdiri dari tiga tahap. Pada Tahap pertama, sampel seniman topeng dipilih secara porporsive sampling berdasarkan tingkat pengetahuan dan kemampuan seniman rakyat di desa tersebut berdasarkan informasi masyarakat setempat. Dalam satu desa tersebut terdapat seperangkat karya rupa topeng Malangan yang didukung oleh fasilitas pembuatan, pelestarian, dan pertunjukannya.

Tahap kedua, rekonstruksi melalui pengukuran artefak, foto, dan montase serta gambar gambar seni rupa akan diperoleh hasil berupa konfigurasi visual elemen dan prinsip rupa dan detail ragam hiasnya. Foto maupun gambar konfigurasi visual elemen rupa yang 
merupakan hasil analisa dari tahap pertama tersebut kemudian dicetak dan dipeta atau dibukukan. Rekonstruksi ini kemudian digunakan sebagai stimulus pada pengumpulan data pada tahap ketiga.

Pada tahap ketiga, konfiguasi visual hasil analisa sebelumnya, dipaparkan kembali kepada penduduk setempat, pemangku adat dan sosial desa dan penduduk kunci dan penghuni sampel yang terpilih. Tujuannya adalah untuk mendapatkan penjelasan masyarakat terhadap hubungan, fungsi dan arti konfigurasi visual Karya rupa berdasarkan apa yang mereka pahami selama mereka tinggal dan berkesenian di kawasan tersebut sebagai hasil dari pengalaman sehari-hari yang mereka alami di dalam lingkungan desa.

\section{Hasil dan Pembahasan}

\subsection{Konfigurasi Visual dan Fisikal Unsur-unsur Rupa Topeng Malangan}

Topeng Malangan terdiri dari 78 figur, dimana terbagi dalam empat karakter utama yaitu panji, antagonis, abdi, dan binatang. Warna Topeng Malangan beraneka ragam dan masing-masing mendeskripsikan makna atau karakter tokoh yang berbeda-beda, yaitu:

a. Warna emas/putih melambangkan kesucian atau sifat setia,

b. Warna merah melambangkan karakter pemberani,

c. Warna kuning melambangkan kesenangan atau sifat ceria,

d. Warna hijau melambangkan kesuburan atau kedamaian, dan

e. Warna biru/hitam melambangkan sifat bijaksana.

Warna-warna di atas ditunjukkan dalam gambar berikut ini:
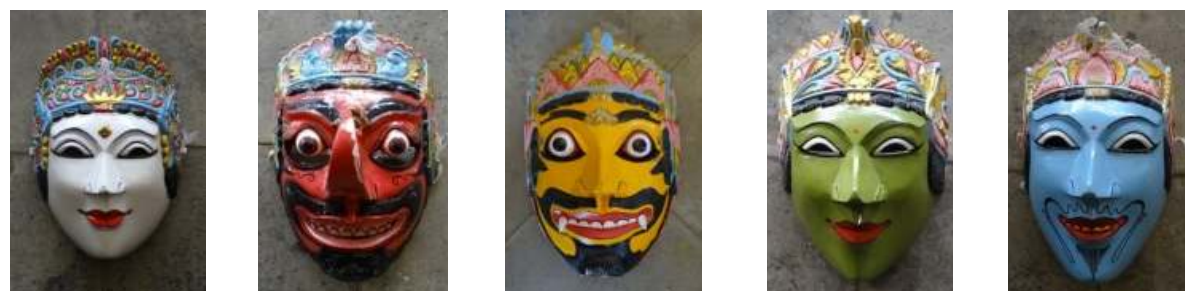

\section{Gambar 1. Unsur warna dasar mendeskripsikan karakter tokoh Topeng Malangan}

(Sumber: Hasil observasi, 2013)

Secara garis besar Topeng Malangan memiliki beberapa klasifikasi unsur rupa sebagaimana halnya dengan anatomi wajah manusia serta didukung oleh beragam karakteristik ragam hiasnya untuk memperkuat karakter tokoh yang divisualisasikan. Bagian-bagian dalam Topeng Malangan ditunjukkan dalam sketsa di bawah ini:

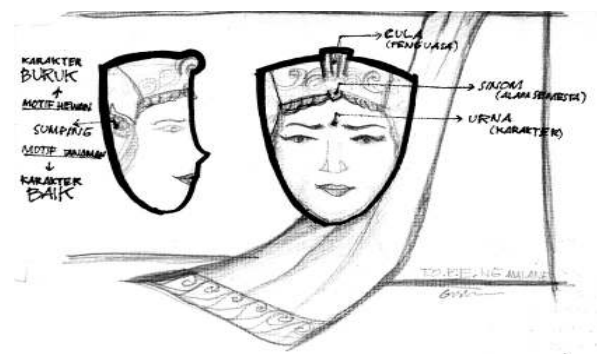

Gambar 2. Sketsa bagian-bagian pada Tópeng Malangan

(Sumber: Hasil observasi, 2013) 
Penamaan tiap ragam unsur tersebut sebagian besar berkaitan dengan makna filosofis alam semesta beserta isinya. Adapun unsur-unsur rupa Topeng Malangan terdiri dari alis, urna/cula, kumis, mulut, hidung, mata, sumping, rambut, dan soul path. Bagianbagian tersebut utamanya untuk menciptakan karakter-karakter protagonis dan antagonis.

\subsection{Unsur Rupa dalam Tari Topeng Malangan}

Seni tari topeng Malangan terdiri dari 15 cerita. Penelitian ini mengambil cerita Rabine Panji sebagai sebuah sampel untuk dianalisis lebih lanjut tentang hubungannya dengan unsur-unsur rupa Topeng Malangan. Penentuan sampel tersebut berdasarkan kriteria cerita klimaks dalam seni tari Topeng Malangan. Di dalam cerita tersebut terdapat enam tokoh utama, yaitu tokoh Panji (protagonis), tokoh Sabrang (antagonis: Klono dan Patih), tokoh Dewi, tokoh Raja Sabrang, tokoh Emban, dan tokoh Demang. Kostum yang digunakan setiap tokoh memiliki beragam warna dan ragam hias:
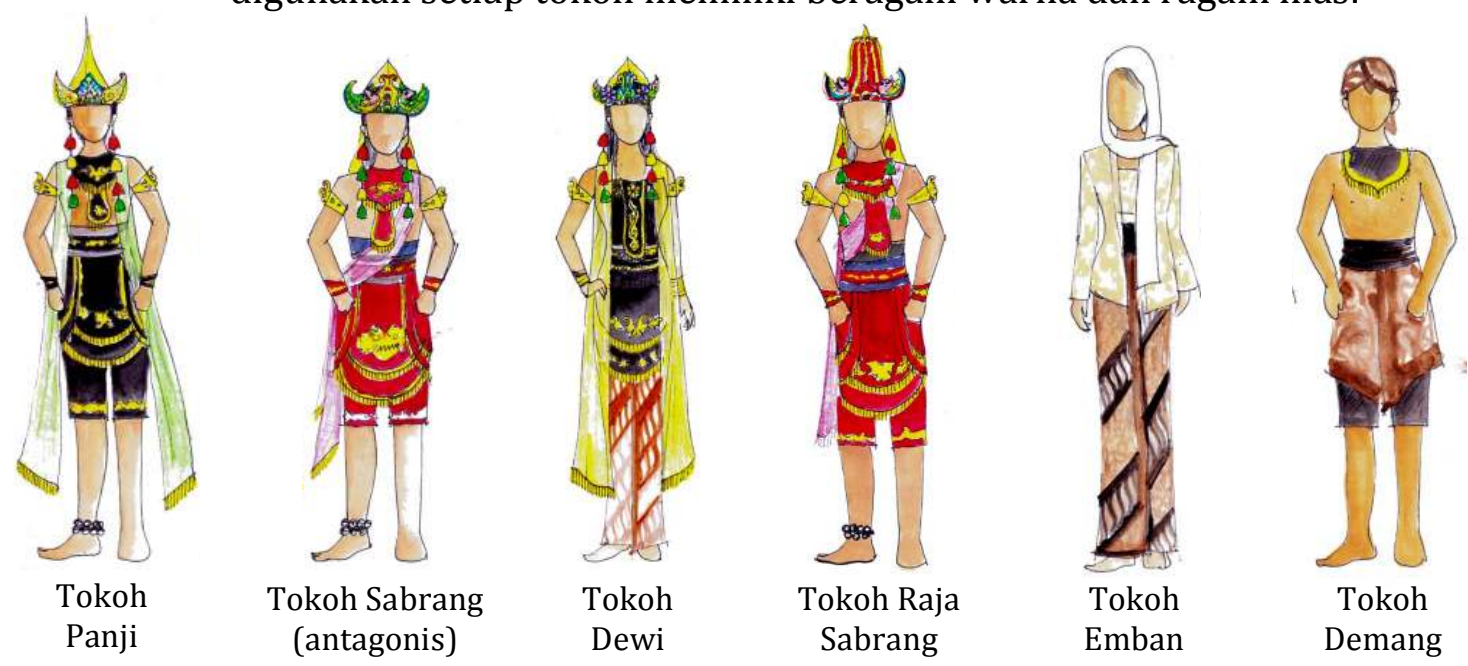

\section{Gambar 3. Tampilan kostum tokoh-tokoh dalam cerita Rabine Panji}

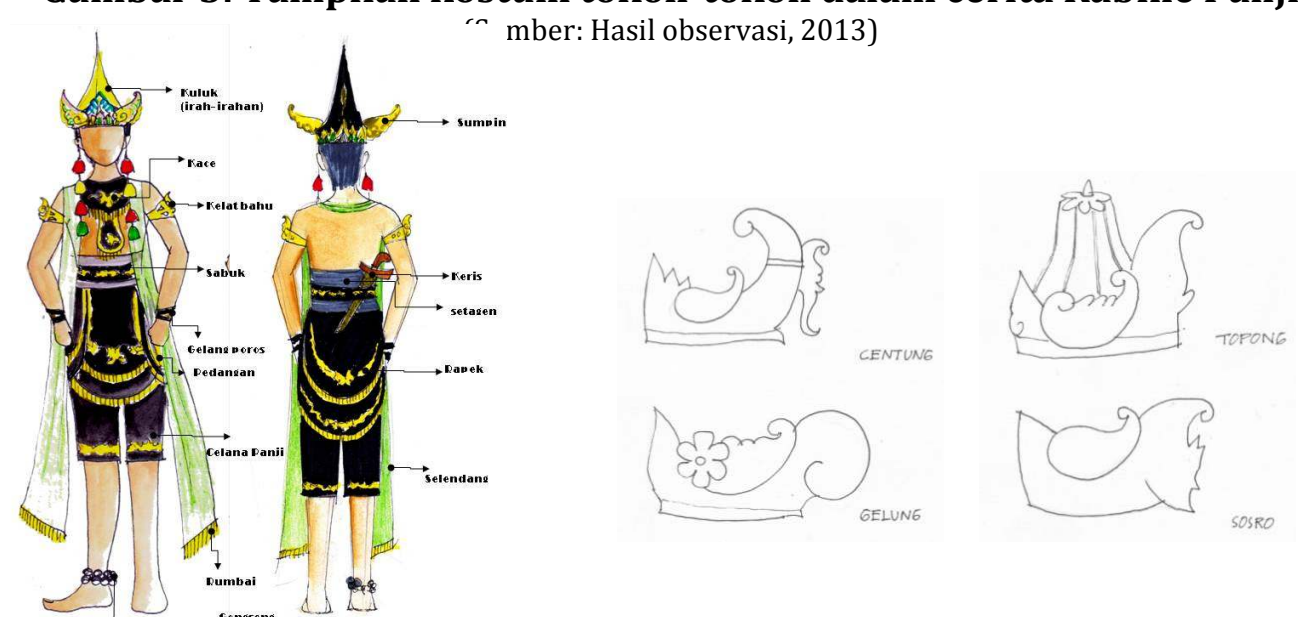

Gambar 5. Bagian-bagian kostum penari Topeng Malangan

dan ragam kuluk (irah-irahan)

(Sumber: Hasil observasi, 2013) 


\subsection{Analisis Hubungan Unsur-unsur Rupa Topeng Malangan}

Unsur-unsur rupa Topeng Malangan yang meliputi karakter, profil, warna, ragam hias, dan formasi gerak tari dianalisis hubungan/interelasi antara satu dengan lainnya. Tanda atau semiotika dapat dijadikan alat untuk menelusuri sesuatu dan menghasilkan sesuatu berupa tanda-tanda atau simbol-simbol. Unsur-unsur rupa topeng Malangan dianalisis semiotiknya mengenai tiga hal, yaitu:

a. Sintaksis, merupakan aktivitas yang mempelajari tanda dalam sistem tanda yang lain yang menunjukkan kesamaam atau kerjasama.

b. Semantik, mempelajari hubungan antara tanda dan maknanya atau denotasi dan konotasi dari tanda tanda tersebut.

c. Pragmatik, mempelajari hubungan tanda dengan pemakainya.

Hasil analisis semiotika tersebut diuraikan dalam tabel di bawah ini:

\section{Tabel 1. Analisis Semiotik Rupa Topeng Malangan}

\begin{tabular}{|c|c|c|c|c|}
\hline No. & Nama Tokoh & Analisis Sintaksis & Analisis Semantik & Analisis Pragmatik \\
\hline 1. & $\begin{array}{l}\text { Raja Lembu } \\
\text { Amijaya }\end{array}$ & $\begin{array}{l}\text { - Warna muka: Hitam } \\
\text { - Bentuk Mata: Gabahan } \\
\text { - Bentuk hidung: Pangotan } \\
\text { - Bentuk mulut: Dlimo pecah } \\
\text { - Bentuk Alis: Blarak sumeret } \\
\text { - Kumis: Kucing anjlok } \\
\text { - Ragam Hias } \\
\text { Cula: bunga wijaya kusuma; } \\
\text { Sumping : Nogosekar; Mahkota: } \\
\text { Topong }\end{array}$ & $\begin{array}{l}\text { Maknanya adalah } \\
\text { kebijaksanaan }\end{array}$ & $\begin{array}{l}\text { Sebagai pengarah } \\
\text { dan penentu } \\
\text { jalannya lakon }\end{array}$ \\
\hline 2. & Patih Kadanawarsa & $\begin{array}{l}\text { - Warna muka: Merah } \\
\text { - Bentuk Mata: Gabahan } \\
\text { - Bentuk hidung: Pangotan } \\
\text { - Bentuk mulut: Dlimo pecah } \\
\text { - Bentuk Alis: Blarak sumeret } \\
\text { - Kumis: Kucing anjlok } \\
\text { - Ragam Hias } \\
\text { Cula: bunga wijaya kusuma; } \\
\text { Sumping : Minangko; Mahkota: } \\
\text { Sosro }\end{array}$ & $\begin{array}{l}\text { Maknanya kesetiaan } \\
\text { dan keberanian }\end{array}$ & $\begin{array}{l}\text { Sebagai pendamping } \\
\text { dan penjaga } \\
\text { sekaligus } \\
\text { komunikator }\end{array}$ \\
\hline
\end{tabular}


Lanjutan Tabel 1

\begin{tabular}{|c|c|c|c|c|}
\hline No. & Nama Tokoh & Analisis Sintaksis & Analisis Semantik & Analisis Pragmatik \\
\hline 3. & $\begin{array}{l}\text { Panji Asmara } \\
\text { Bangun }\end{array}$ & $\begin{array}{l}\text { - Warna muka: Hijau } \\
\text { - Bentuk Mata: Gabahan } \\
\text { - Bentuk hidung: Pangotan } \\
\text { - Bentuk mulut: Dlimo mletek } \\
\text { - Bentuk Alis: Blarak sumeret } \\
\text { - Kumis: Kucing anjlok } \\
\text { - Ragam Hias } \\
\text { Cula: bunga wijaya kusuma; } \\
\text { Sumping: Sodo; Mahkota: Gentong }\end{array}$ & $\begin{array}{l}\text { Maknanya } \\
\text { kesuburan dan } \\
\text { kedamaian }\end{array}$ & $\begin{array}{l}\text { Sebagai sentral } \\
\text { cerita dan duta }\end{array}$ \\
\hline 4. & Raden Gunungsari & $\begin{array}{l}\text { - Warna muka: Putih } \\
\text { - Bentuk Mata: Gabahan } \\
\text { - Bentuk hidung: Pangotan } \\
\text { - Bentuk mulut: Dlimo mletek } \\
\text { - Bentuk Alis: Blarak sumeret } \\
\text { - Kumis: Kucing anjlok } \\
\text { - Ragam Hias } \\
\text { Cula: bunga wijaya kusuma; } \\
\text { Sumping: Nogosekar; Mahkota: } \\
\text { Gentong }\end{array}$ & $\begin{array}{l}\text { Maknanya kesucian } \\
\text { dan keteladanan }\end{array}$ & $\begin{array}{l}\text { Sebagai penasihat } \\
\text { dan penutur }\end{array}$ \\
\hline 5. & $\begin{array}{l}\text { Bapang Jaya } \\
\text { Sentika }\end{array}$ & $\begin{array}{l}\text { - Warna muka: Merah } \\
\text { - Bentuk Mata: Dondongan } \\
\text { - Bentuk hidung: Bapangan } \\
\text { - Bentuk mulut: Singo barong } \\
\text { - Bentuk Alis: Kuwel } \\
\text { - Kumis: Nunggeng } \\
\text { - Ragam Hias } \\
\text { Cula: bunga matahari; Sumping: } \\
\text { Pudak mekar; Mahkota: Sosro }\end{array}$ & $\begin{array}{l}\text { Maknanya berontak } \\
\text { dan keberanian }\end{array}$ & $\begin{array}{l}\text { Sebagai pembuat } \\
\text { masalah }\end{array}$ \\
\hline
\end{tabular}

Representasi tokoh-tokoh dalam analisis sintaksis, semantik, dan pragmatik di atas berhubungan dengan simbol warna tradisonal Jawa (Jawa timur) antara alam lingkungan dan perwatakan manusianya. Adapun hubungan antara warna dan simbol tersebut diuraikan berikut ini:

a. Warna Hitam diambil dari simbol tanah

b. Warna Merah diambil dari simbol api

c. Warna Putih diambil dari simbol udara

d. Warna Hijau diambil dari simbol tumbuhan 
e. Warna Biru diambil dari simbol air

Hasil sintesis ini dapat lebih luas dalam menginterpretasikan hasilnya dan yang perlu distudi atau dikaji lebih lanjut adalah hubungannya dengan desain dan arsitektur berikutnya.

\section{Simpulan}

Topeng Malangan memiliki beragam warna, ukiran, serta simbol-simbol dalam ragam hiasnya yang sangat khas. Topeng Malangan dengan karakteristiknya tersebut dapat melengkapi karakteristik watak dari setiap tokoh yang dimainkan dalam tarian dengan beragam ceritanya serta beragam warna maupun ragam hias dalam kostum penarinya. Pada dasarnya topeng Malangan merepresentasikan karakter utama manusia di muka bumi ini yaitu karakter jahat/buruk dan baik/bijaksana. Bentuk anatomi wajah manusia khususnya alis, kumis, mulut, hidung, mata, rambut, dan soul path hadir dalam setiap topeng Malangan sesuai dengan karakter/watak tokoh yang diperankan. Representasi tokoh-tokoh dalam analisis sintaksis, semantik, dan pragmatik di atas berhubungan dengan simbol warna tradisonal Jawa (Jawa timur) antara alam lingkungan dan perwatakan manusianya. Oleh sebab itu, simbolisme atau pemaknaan tanda dalam topeng Malangan juga merupakan salah satu bentuk apresiasi terhadap keindahan alam semesta beserta isinya yang melingkupi kehidupan manusia di muka bumi.

\section{Daftar Pustaka}

Bagus, IGN. editor Koentjaraningrat. 1987). "Kebudayaan Bali" dalam Manusia dan KebudayaanIndonesia, cetakan 11, Jakarta: Djambatan

Bastomi, Suwadji. 1993. Nilai-nilai Seni Pewayangan. Semarang: Dahara Prize

Berger, Peter dan Thomas Luchkman, Hasan Basri (penter). 1990.Tafsir Sosial atas Kenyataan:Risalah Tentang Sosiolog. Jakarta: LP3ES

Bosch, FDK. 1981. Masalah Penyebaran Kebudayaan Hindu di Indonesia. Jakarta: Bratara

Daeng, Hans. J. 2000. Manusia, Kebudayaan dan Lingkungannya. Tinjauan

Antropologis. Cetakan I. Jogyakarta: Pustaka Pelajar (IKAPI)

Mulyono, Sri. 1983.Wayang dan Karakter Manusia. Jakarta: Gunung Agung

----------. 1979. Simbolisme dan Mistikisme dalam Wayang. Jakarta: Gunung Agung

---------. 1989. Wayang: Asal-usul, Filsafat dan Masa Depannya. Jakarta: Gunung Agung

Murgiyanrto, Sal. Pertunjukan Topeng di Jawa", Analisis Kebudayaan, Depdikbud, Th. 1nomor 2, 1980/1981

Peursen, c.a. van. 1976. Strategi Kebudayaan, cetakan pertama. Jogyakarta:

Yayasan Kanisius

Sedyawati, Edi. 1993Seni Pertunjukan Indonesia, “Topeng Dalam Budaya”. Jurnal Masyarakat SeniPertunjukan Indonesia. Jakarta: Diterbitkan atas kerjasama Masyarakat Seni

PertunjukanIndonesia dengan PT. Gramedia Widiasarana Indonesia

Singarimbun, Masri. 1989. ed. Metode Penelitian Survai. edisi revisi. Jakarta: LP3ES

Soekanto, Soerjono. 1987. Sosiologi Suatu Pengantar. Edisi Baru ketiga, cetakan

Kedelapan. Jakarta: Penerbit CV. Rajawali

Spradley, James P. 1997. Metode Etnografi, pengantar DR. Amri Marzali, MA.

Jogyakarta: PT TiaraWacana

Sukadana, A. Adi. 1983. Antropo Ekologi . Surabaya: Airlangga University Press

Jurnal RUAS, Volume 11 N0 2, Desember 2013, ISSN 1693-3702 
Wibisono, Singgih. 1991. "Wayang Sebagai Sarana Komunikasi" dalam Sedyawati, Seni DalamMasyarakat Indonesia . Jakarta: PT. Gramedia Pustaka Utama

Sachari, Agus. 2005. Pengantar Metodologi Penelitian Budaya Rupa. Jakarta: Erlangga

Wong, Wucius. 1986. Beberapa Azas merancang Dwi-Matra. Bandung: ITB

Wong, Wucius. 1989. Beberapa Azas merancang Tri-Matra. Bandung: ITB

Zahnd, Markus. 2009. Pendekatan dalam perancangan arsitektur. Semarang: Soegiapranata University press 